\title{
Pentingnya Materi Lingkungan Terhadap Pembelajaran Bahasa Indonesia di Sekolah
}

\author{
Ayu Puji Lestari/18016143 \\ Univeristas Negeri Padang-FBS \\ ayupujilestari310799@gmail.com
}

Dalam kehidupan lingkungan memiliki peran yang sangat penting. Materi lingkungan dapat dikaitkan dengan pembelajaran bahasa Indonesia. Dalam pembelajaran bahasa Indonesia materi lingkungan sangat penting, sebab dengan mempelajari materi lingkungan peserta didik akan memiliki pemahaman yang baik tentang materi lingkungan, sehingga peserta didik memiliki kepekaan dan kepedulian terhadap lingkungan, terutama lingkungan kelas pada saat pembelajaran bahasa Indonesia.

Lingkungan adalah mencangkup segala hal yang ada dik sekitar kita. Ramadhan, Sukma , dan Indriyani (2019) setiap Individu memiliki kewajiban yang sama untuk melindungi lingkungan. Selain itu, Ramadhan, Sukma, dan Indriyani (2019) juga mengatakan "environmental problems are inherently inseparable from environmental awareness, values, and attitudes of people. This encourages countries to start assessing environmental education". Masalah lingkungan pada dasarnya tidak dapat dipisahkan dari kesadaran lingkungan, nilai-nilai, dan sikap masyarakat. Hal ini mendorong negara untuk mulai menilai pendidikan lingkungan." Salah satu masalah yang sering terjadi adalah kebersihan lingkungan sekitar. Masyarakat kurang menyadari bahwa tindakannya tersebut bisa merusak lingkungan.

Lingkungan mempengaruhi kesantunan seseorang dalam berbahasa. Sejalan dengan itu, Noibe Halawa (2019) kesantunan merupakan kebiasaan kebiasaan menyangkut perilaku yang berlaku dalam masyarakat. Dalam situasi kehidupan sehari-hari, sikap yang yang santun akan memberi dampak positif terhadap hubungan sosial dan lingkungan sekitar. Selain iti, lingkungan juga mempengaruhi pemerolehan bahasa pada anak. Suardi, Ramadhan, Asri (2019) pemerolehan bahasa pada anak dalam aspek fonologi di pengaruhi faktor lingkungan khususnya keluarga hal tersebut ditandai dengan banyaknya pembendaharaan kosakata yang mereka dapatkan di lingkungan keluarga dan sekitar.

Menurut Ramadhan, Sukma, dan Indriyani (2019) individu harus didorong untuk tidak memandang lingkungan sebagai sesuatu yang harus dieksploitasi untuk tujuan mereka, tetapi 
sebagai aset yang berharga yang harus dilindungi demi kelangsungan hidup manusia. Sukma (2020) mengatakan sebagai individu, manusia memiliki tanggung jawab untuk menyelesaikan masalah lingkungan. Salah satu solusi yang dapat dilakukan untuk mengatasi masalah lingkungan adalah dengan memiliki pengetahuan yang benar tentang semua faktor lingkungan untuk menjaga lingkungan.

Ramadhan, Sukma, dan Indriyani (2019) tujuan dari pendidikan lingkungan adalah untuk membuat siswa berpartisipasi dalam melindungi lingkungan. Sejalan dengan hal ini, Sukma (2020) mengatakan tujuan pendidikan lingkungan dapat diidentifikasi sebagai transformasi positif dari etika lingkungan individu, pengetahuan lingkungan, kesadaran lingkungan, sikap dan perilaku lingkungan. Pengetahuan lingkungan, minat dan sikap masyarakat terhadap lingkungan efektif dalam perilaku mereka terhadap lingkungan. Padahal, peran penting pendidikan lingkungan adalah mengembangkan individu yang memiliki pengetahuan ilmiah tentang masalah lingkungan dan kesadaran lingkungan yang tinggi. Selain itu, memiliki potensi untuk membantu generasi penerus mengelola kehidupan dan membangun masa depan yang sejahtera.

Menurut Ramadhan, Sukma, dan Indriyani (2019) guru berperan penting dalam pengajaran pendidikan lingkungan dan menumbuhkan kesadaran siswa tentang lingkungan. Sukma (2015) Interaksi belajar-mengajar yang terjadi di dalam kelas merupakan interaksi timbal-balik antara guru dengan siswa maupun guru dengan siswa-siswa. Guru juga memiliki peranan yang penting dalam mengajarkan materi lingkungan kepada siswa. Guru juga harus mengembangkan kemampuan siswa dalam memahami, mengkritik, dan berpartisipasi secara rasional dalam setiap wacana tentang masalah lingkungan. Dalam pembelajaran bahasa Indonesia guru pasti memiliki kendala dalam proses pembelajaran terutama pada aspek kognitif, yaitu kurangnya pemahaman guru dalam mengajar (Sukma, 2019).

Sukma (2016) Unesco melaporkan tingkat penguasaan bahan ajar dan keterampilan dalam menggunakan metode mengajar yang inovatif masih kurang, umumnya guru menggunakan metode ceramah . Ramadhan , Asri dan Indriyani ( 2018) model pembelajaran yang inovatif mampu meningkatkan hasil belajar peserta didik. Melalui pendidikan lingkungan ini bisa membantu guru dalam menyampaikan materi pembelajaran kepada siswa. Misalnya, saat siswa ditugasi dalam membuat puisi yang bertemakan lingkungan, seorang guru bisa menyuruh siswanya mengamati lingkungan disekitarnya agar bisa menghasilkan puisi yang bagus. Jaya, 
Ramadhan dan Ermanto (2013) guru harus menyesuaikan dengan lingkungan dan tingkat pemahaman siswa sehingga gambaran ide dan gagasan puisi siswa lebih jelas. Ramadhan, Sukma, dan Indriyani (2019) penggunaan tema lingkungan dalam pembelajaran teks dapat memicu minat belajar bahasa siswa dan secara implisit dapat meningkatkan pengetahuan siswa tentang lingkungan. Angin, Ramadhan, dan Agustina (2015) siswa lebih peka terhadap lingkungannya karena dapat menyajikan hasil pengamatannya terhadap apa yang dilihatnya dalam kehidupan sehari-hari.

Materi lingkungan yang diajarkan di sekolah maupun di perguruan tinggi merupakan kebijakan para ahli pendidikan yang perlu dipuji, dengan mempelajari materi lingkungan dari dini, baik dari sekolah maupun perguruan tinggi dapat menumbuhkan kepedulian akan pentingnya dan melestarikan lingkungan masing-masing. Menurut Ramadhan, Sukma, and Indriyani (2019) mengemukan pendidikan lingkungan penting untuk meningkatkan sikap dan kesadaran siswa terhadap lingkungan.

Menurut Ramadhan, Sukma, dan Indriyani (2019) siswa perlu memiliki pengalaman yang baik dalam memahami dan mengatasi setiap perubahan global dan lingkungan masyarakat. Menurut Ramadhan Sukma, dan Indriyani (2019) agar siswa berpatisipasi dalam melindungi lingkungan, penting untuk mengembangkan pengetahuan tentang lingkungan, kesadaran lingkungan dan perubahan perilaku terhadap lingkungan. Safitri dan Sukma (2020) pemilihan sumber belajar harus sesuai dengan karakteristik siswa agar sumber belajar yang digunakan dapat menunjang kemampuan siswa dalam belajar secara optimal.

Berdasarkan permasalahan di atas, penulis telah menyebarkan angket mengenai pentingnya materi lingkungan terhadap pembelajaran bahasa Indonesia di sekolah yang ditujukan kepada mahasiswa S1 dari berbagai jurusan, universitas dan juga jenis kelamin. Penelitian yang dilakukan adalah dengan membuat sepuluh butir pernyataan tentang pentingnya materi lingkungan dalam bahasa Indonesia dalam bentuk angket google form. Hasil yang didapatkan dari penelitian itu adalah sebagai berikut. Butir pertama, dalam pembelajaran bahasa Indonesia materi lingkungan sangat penting, yang menyatakan sangat setuju $(57,4 \%)$, setuju $(42,6 \%)$, kurang setuju dan tidak setuju (0\%). Butir kedua, dalam pembelajaran bahasa Indonesia, materimateri yang bertemakan lingkungan merupakan salah satu strategi untuk menambah kosakata, yang menyatakan setju (63\%), sangat setuju (37\%), kurang setuju dan tidak setuju (0\%). Butir 
ketiga, dalam pembelajaran bahasa Indonesia guru mengajak siswa untuk lebih mencintai lingkungan sekitar, yang menyatakan sangat setuju (57,44\%), setuju $(42,6 \%)$, kurang setuju dan tidak setuju (0\%). Butir keempat, materi lingkungan dalam pembelajaran bahasa Indonesia berkaitan dengan penggunaan bahasa Indonesia dalam kehidupan sehari-hari, yang menyatakan sangat setuju (52,8\%), setuju (47,2\%), kurang setuju dan tidak setuju (0\%). Butir kelima, dalam pembelajaran bahasa Indonesia materi lingkungan berkaitan dengan lingkungan sosial, lingkungan alam, dan lingkungan hidup, yang menyatakan sangat setuju (51,9\%), setuju $(48,1 \%)$, kurang setuju dan tidak setuju (0\%). Butir keenam, materi lingkungan dalam pembelajaran bahasa Indonesia bertujuan untuk terjadinya proses komunikasi atau interaksi antara siswa dan lingkungan, yang menyatakan sangat setuju $(57,4 \%)$ setuju $(42,6 \%)$, kurang setuju dan tidak setuju (0\%). Butir ketujuh, saat pembelajaran bahasa Indonesia guru harus mengajak siswa untuk menjaga dan melestarikan lingkungan, yang menyatakan sangat setuju $(59,3 \%)$, setuju (40,7\%), kurang setuju dan tidak setuju (0\%). Butir kedelapan, materi tentang lingkungan dalam pembelajaran bahasa Indonesia membuat siswa peduli akan kebersihan lingkungan, yang menyatakan sangat setuju (50\%), setuju (50\%), kurang setuju dan tidak setuju (0\%). Butir kesembilan, keuntungan adanya materi lingkungan dalam pembelajaran bahasa Indonesia adalah siswa dapat menghargai dan menjaga lingkungan dengan baik, yang menyatakan setuju (59,3\%), sangat setuju (40,7\%, kurang setuju dan tidak setuju (0\%). Dan butir terakhir, materi lingkungan dalam pembelajaran bahasa Indonesia sangat dianjurkan bagi siswa, yang menyatakan sangat setuju (50\%), dan setuju (50\%), kurang setuju dan tidak setuju (0\%).

Berdasarkan hasil penelitian penulis diatas dapat disimpulkan bahwa materi lingkungan dalam pembelajaran bahasa Indonesia di sekolah memang sangat penting. Hal ini terlihat dari jawaban responden yang menyatakan positif tentang pentingnya materi lingkungan dalam bahasa Indonesia. Dengan dengan adanya materi lingkungan akan membantu dalam proses pembelajaran. Selain itu, peserta didik akan semakin menjaga dan melestarikan lingkungannya, menumbuhkan sikap peka terhadap situasi dan kondisi lingkungan sekitar dan membangun karakter yang jujur, disiplin, empati, dan optimis serta religius. Tulisan ini bertujuan agar masyarakat dan peserta didik dapat menjaga kelestarian lingkungan. 


\section{Daftar Rujukan}

Angin, Toras Barito Bayo, Syahrul R, Agustina. 2015. Pengembangan Modul Berbasis Pendekatan Kontekstual Pada Menulis Iklan Di Kelas VIII SMP 2 Padangsidipuan Sumatera Utara. Jurnal Bahasa, Sastra dan Pembelajaran. Volume 3 Nomor 1.

Halawa, Noibe, Erizal Gani, Syahrul R. 2019. Kesantunan Berbahasa Indonesia Dalam Tindak Tutur Melarang dan Mengkritik Pada Tujuh Etnis. Jurnal Lingua. Volume XV. Nomor 2.

Ramadhan, S., Asri, Y., \& Indiryani, V. Learning Module Design Writing Argumentative Text Based Problem-Based Learning. In Advances In Social Science: Education And Humanities Research. Volume 263, Pp. 194-200.

Ramadhan, S., Sukma, E., \& Indriyani, V. 2019. Environmental education and disaster mitigation through language learning. IOP Conference Series: Earth and Environmental Science, 314

Safitri, Annisa, Elfia Sukma. 2020. Peningkatan Hasil Belajar Siswa Pada Tema 3 Menggunakan Pendekatan Saintifik di Sekolah Dasar. Jurnal Pendidikan Tambusai. Volume 4, Nomor 3.

Suardi, Indah Permatasari, Syahrul R, Yasnur Asri. Pemerolehan Bahasa Pertama pada Anak Usia Dini. Jurnal Obsesi : Jurnal Pendidikan Anak Usia Dini. Volume 3 Issue 1 (2019) Pages $265-273$.

Suhatman Jaya, Syahrul R, Ermanto . 2013. Peningkatan Keterampilan Menulis Puisi Melalui Media Gambar Siswa Kelas X.1 Sma Negeri 2 Kota Sungai Penuh . Jurnal Bahasa, Sastra Dan Pembelajaran. Volume 1 Nomor 2,

Sukma E., S Ramadhan, V Indriyani. 2020. Integration of environmental education in elementary schools. Journal of Physics: Conf. Series 1481.

Sukma, Elfia. 2015. Penerapan Pendekatan Komunikatif Dalam Pembelajaran Struktur Bahasa Indonesia Di Skeolah Dasar. Jurnal Diksi. Vol. 12, No. 1.

Sukma, Elfia. 2016. Kompetensi Kognitif Pembelajaran Apresiasi Sastra Di Sekolah Dasar. Jurnal Gramatika V2. i1 (1-11).

Sukma, Elfia. 2019. Problem in Oral Language Teaching in Primary School. Seventh internation conference on languanges and arts (ICLA 2018). Atlantis Press. 